\title{
Walking the talk of food systems at a small land-grant university: Overcoming process barriers to a transdisciplinary approach
}

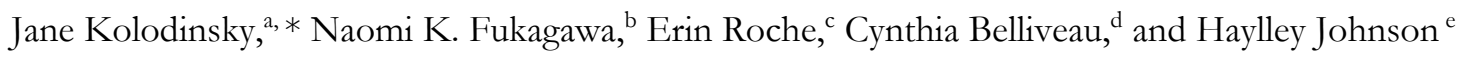 \\ University of Vermont
}

Submitted 1 December 2011 / Revised 27 April and 1 June 2012 / Accepted 7 June 2012 / Published online 20 June 2012

Citation: Kolodinsky, J., Fukagawa, N. K., Roche, E., Belliveau, C., \& Johnson, H. (2012). Walking the talk

of food systems at a small land-grant university: Overcoming process barriers to a transdisciplinary

approach. Journal of Agriculture, Food Systems, and Community Development, 2(3), 149-159.

http://dx.doi.org/10.5304/jafscd.2012.023.015

Copyright (C) 2012 by New Leaf Associates, Inc.

\begin{abstract}
In this paper we present the evolution of a transdisciplinary food systems (FS) initiative at a small land-grant university. The first indication of the relevance of food systems study at this university came from faculty and students, which
\end{abstract}

All authors are associated with the University of Vermont Food Systems Transdisciplinary Initiative.

a, * Corresponding author: Jane Kolodinsky, Community Development and Applied Economics, University of Vermont, Central Campus, Burlington, VT 05405 USA; \ane.Kolodinsky@uvm.edu

b Naomi K Fukagawa, College of Medicine, University of Vermont

${ }^{\mathrm{c}}$ Erin Roche, Center for Rural Studies, University of Vermont

${ }^{\mathrm{d}}$ Cynthia Belliveau, Continuing Education, University of Vermont

e Haylley Johnson, Food Systems Spire, University of Vermont. then progressed to the establishment of structural changes and financial support by the administration. This commentary demonstrates that successfully incorporating transdisciplinary academic support, research, and educational programs is not an easy endeavor and requires multilevel buy-in from all strata within the organization. This approach also takes substantial time and resource commitment from faculty, staff, students, administration, and the community. If approached in a holistic, transdisciplinary manner, FS initiatives will link what universities do best with improvement in the FS continuum from food production to public health. As with most new initiatives, there are both barriers and triggers to success, and work is ongoing. Using the lens of the University of Vermont (UVM), this paper poses questions and provides best practice advice to others who seek collaboration across disciplines that goes beyond inter- or multidisciplinarity collaboration. 


\section{Keywords}

community partners, food systems, higher education, Higher Education Challenge Grant, organizational development, transdisciplinary, Vermont

\section{Introduction}

Universities across the country are embracing the concept of food systems. With its historic niche in smaller-scale approaches, a small land base, varied topography, harsh climate, and limited infrastructure, Vermont and the University of Vermont (UVM) should be well positioned to successfully contribute to instruction, research, and outreach in the area of smaller, regionally based food systems. Vermont residents and visitors value food and farming, resulting in the highest per capita directmarket sales in the nation (Strolling of the Heifers, 2012). Interest in a regional approach is growing nationally with growth in local, sustainable food production, a growing number of farmers' markets (U.S. Department of Agriculture [USDA] Agricultural Marketing Service, 2011) and an increasing demand for organic foods (USDA Economic Research Service, 2009).

Incorporating food systems into curriculum, research, and outreach is a challenge for any university that sees FS as a meaningful way to maintain relevance in today's world. Decisions need to be made about whether to repackage existing programs with a new name that includes "food systems" or to build new programs from the bottom up and rename them later. UVM chose the latter, using a staged planning approach that was facilitated by a U.S. Department of Agriculture (USDA) Higher Education Challenge Grant to develop a Food Systems Masters Program. At that time (2009), fewer than five universities had programming specifically named food systems. By 2012, most of the land-grants and many other universities listed food systems programming on their websites. At UVM, it took three years for final approval of a Food Systems Master of Science degree, which occurred in February 2012. However, UVM has yet to offer an undergraduate major with the specific designation of food systems. Challenging factors such as faculty governance over the curriculum and the multiple disciplines involved in FS courses contributed to a process that raised questions for which many universities trying to "walk the talk" of food systems may not have immediate or complete answers.

\section{Background: Transdisciplinarity vs. Multidisciplinarity vs. Interdisciplinarity} Universities are typically designed around "disciplinary silos," where each department has its focus of expertise, each faculty member has his or her own research program, and each discipline has its own journal. However, a transdiciplinary approach is called for when knowledge about a societally relevant problem field is uncertain, when the concrete nature of problems is disputed, and when there is a great deal at stake for those concerned by problems and involved in dealing with them (Pohl, von Kerkhoff, Hirsch Hadorn, \& Bammer, 2008). Few would argue that the planet's food system is not at a critical juncture. Food systems solutions to negative impacts of climate change, growing populations, and obesity, superimposed with food insecurity, require transdisciplinary solutions. Therefore, as universities formulate structures for food systems offerings, they must think about how transdisciplinarity differs from multidisciplinarity and interdisciplinarity and how or whether higher education can adapt to the changes required by this evolving paradigm.

The descriptor transdisciplinary differs from multidisciplinary and interdisciplinary. Multidisciplinary refers to faculty from different disciplines addressing a particular problem independently and staying within their specific disciplinary framework (Wickson, Carew, \& Russell, 2006). Interdisciplinary refers to "a mode of inquiry by teams of individuals that integrate information, data, techniques, tools, perspectives, concepts, and/or theories from two or more disciplines or bodies of specialized knowledge to advance fundamental understanding or to solve problems whose solutions are beyond the scope of a single discipline" (National Research Council of the National Academies [NRC], 2004, p. 39). Transdisciplinarity extends beyond a "linear application of a static methodology and aims for an evolving, dynamic or 
responsive methodology that is iterative and an ongoing part of the research process" (Wickson, et al., 2006, p. 1051). Faculty from different disciplines use a shared conceptual framework to develop the project by defining the approaches, which are more fluid. The fundamental requirement is that scholars from the different disciplines respect and try to understand the approaches, methods, and theories of others, with the goal of integration rather than parallel function. Baker, Koliba, Kolodinsky, Liang, McMahon, Patterson, and Wang (2009) discuss the movement toward transdisciplinarity of a single department at a landgrant university, but there is a dearth of referred publications devoted to transdisciplinary food systems education, research, and outreach.

In the early 2000 s, several publications discussed the move toward inclusion of sustainable or ecological agriculture in higher education (e.g., Parr, Trexler, Khanna, \& Battisti, 2007) and "the complex character of agriculture" (Fields, Hoiberg, \& Othman, 2003). Only one paper by authors outside the U.S. addressed food systems education, described as "ecological agriculture" (Lieblein et al., 2000). These early approaches planted the seed for food systems as a distinct area of study, but one that included multiple disciplinary approaches with the goal of an integrated effort. Only the Journal of Agriculture, Food Systems, and Community Development has published contemporary papers on food systems education. These have either a disciplinary focus (planning) (Mendes \& Nasr, 2011), speak of interdisciplinarity instead of systemwide approaches to sustainable agriculture programs (Jacobsen, et al., 2012), or use a values based approach as a coordinating umbrella for existing sustainable agriculture programs (Galt, Clark, \& Parr, 2012). A lack of literature on transdisciplinary food systems approaches could be attributable to unintended barriers to these approaches inherent in the structure of our land-grant universities.

There has been growing support for transdiscplinary approaches from the funding agencies on which food system academics often rely. In 2001, the National Research Initiative (NRI) of USDA “encouraged multi-disciplinary research, which is needed to solve complex problems, and seeks to initiate research in new areas of science and engineering that are relevant to agriculture, food, forestry, and the environment" (USDA National Institute of Food and Agriculture, 2001, p. 1), with "integrated" projects added to the 2004 research agenda of the USDA (USDA, 2004, p. 2). Integration as a focus has continued with the Agriculture and Food Research Initiative (AFRI) program, as well as with the National Institutes of Health (NIH) and National Science Foundation (NSF) initiatives. Nevertheless, the challenge of achieving consensus about the value of transdisciplinary approaches (vs. multi- or interdisciplinary) remains.

UVM chose to embrace the transdisciplinary approach. Food systems go beyond sustainable agriculture and can include almost every discipline, from cultural aspects of food studied by anthropologists and the environmental effects of production and consumption studied by environmental scientists, to the political economy and historical relevance of the Columbian exchange on our current food system. Taking a "choose several" (courses) approach to food systems education and research that requires the student or faculty member to "connect the dots" may not lead to student understanding of the complex solutions necessary to solve complex problems, nor researchers' ability to find innovative ways to research complex problems. Movement toward the transdisciplinary is one approach that may.

Table 1 (next page) outlines these questions and some approaches that may alleviate barriers in the process of moving toward a transdisciplinary food systems approach in higher education.

\section{One University's Approach}

Using table 1 as a guide, the following outlines the approach taken at UVM to move toward transdisciplinarity in food systems education, research, and outreach.

\section{Grassroots Faculty Efforts}

\section{The first of two USDA Higher Education Challenge Grants pave the way} In 2003, the College of Agriculture and Life Sciences' (CALS) Department of Community Development and Applied Economics (CDAE) 
Table 1. Questions and Possible Approaches to Moving Toward a Food Systems Approach in Higher Education

\begin{tabular}{|c|c|c|}
\hline \multirow{2}{*}{$\begin{array}{l}\text { Questions } \\
\text { What is the best way to help faculty } \\
\text { have a conversation about } \\
\text { transdisciplinary approaches to } \\
\text { education, research, and outreach? }\end{array}$} & \multicolumn{2}{|c|}{ Spectrum of Possible Approaches } \\
\hline & $\begin{array}{l}\text { Allow conversations to develop } \\
\text { informally and through grassroots } \\
\text { efforts. }\end{array}$ & $\begin{array}{l}\text { Provide formal opportunities to } \\
\text { engage in and facilitate } \\
\text { conversations. }\end{array}$ \\
\hline $\begin{array}{l}\text { Should the process be piecemeal, } \\
\text { introduced in a series of } \\
\text { uncoordinated steps, or a } \\
\text { coordinated effort? }\end{array}$ & $\begin{array}{l}\text { Individual faculty, student, and } \\
\text { organizational unit events are } \\
\text { unconnected and not coordinated. }\end{array}$ & $\begin{array}{l}\text { Provide a central hub for coordinating } \\
\text { events across campus. }\end{array}$ \\
\hline $\begin{array}{l}\text { How does an institution incentivize a } \\
\text { food systems approach? }\end{array}$ & $\begin{array}{l}\text { Individual faculty volunteer time and } \\
\text { organizational units provide } \\
\text { resources. }\end{array}$ & $\begin{array}{l}\text { Formal, centralized incentive } \\
\text { packages are offered. }\end{array}$ \\
\hline $\begin{array}{l}\text { Should there be a coordinator across } \\
\text { campus? }\end{array}$ & $\begin{array}{l}\text { No coordinator; faculty initiatives } \\
\text { grow from the bottom up. }\end{array}$ & $\begin{array}{l}\text { A coordinator is appointed to insure } \\
\text { initiatives are woven into a fabric of } \\
\text { food systems activities. }\end{array}$ \\
\hline $\begin{array}{l}\text { Should university resources be } \\
\text { allocated initially or should resource } \\
\text { allocations wait until food systems } \\
\text { initiatives are successful? }\end{array}$ & $\begin{array}{l}\text { Resources are allocated on a case-by- } \\
\text { case basis, provided by individual } \\
\text { units. }\end{array}$ & $\begin{array}{l}\text { The initiative is provided up-front } \\
\text { funding through reallocated or new } \\
\text { resources. }\end{array}$ \\
\hline $\begin{array}{l}\text { Can existing coursework be } \\
\text { repackaged into a food systems } \\
\text { curriculum? }\end{array}$ & $\begin{array}{l}\text { Current courses are rearranged into a } \\
\text { "new" curriculum. }\end{array}$ & $\begin{array}{l}\text { New courses are developed that } \\
\text { specifically address differences in a } \\
\text { transdisciplinary approach. }\end{array}$ \\
\hline $\begin{array}{l}\text { Should new organizational structures } \\
\text { be developed to encourage } \\
\text { transdisciplinary work? }\end{array}$ & $\begin{array}{l}\text { Current department and college } \\
\text { structures remain; faculty reach out } \\
\text { beyond their own organizational } \\
\text { homes. }\end{array}$ & $\begin{array}{l}\text { New structures are added (e.g., } \\
\text { Centers) or new organizational lines } \\
\text { are drawn that facilitate } \\
\text { transdisciplinary work. }\end{array}$ \\
\hline $\begin{array}{l}\text { Should teaching, research, and } \\
\text { outreach components be treated as } \\
\text { separate entities? }\end{array}$ & $\begin{array}{l}\text { The three hallmarks of the land-grant } \\
\text { mission remain separate; } \\
\text { transdisciplinarity is encouraged } \\
\text { within each. }\end{array}$ & $\begin{array}{l}\text { Food systems is recognized as cutting } \\
\text { across the larger mission and is } \\
\text { coordinated in its approach. }\end{array}$ \\
\hline $\begin{array}{l}\text { Are current university governance } \\
\text { systems adequate for } \\
\text { transdisciplinary approaches? }\end{array}$ & $\begin{array}{l}\text { Current systems are used, resulting in } \\
\text { a longer process of implementing a } \\
\text { food systems approach. }\end{array}$ & $\begin{array}{l}\text { Streamlined governance systems are } \\
\text { developed that recognize } \\
\text { complexities of working across units. }\end{array}$ \\
\hline $\begin{array}{l}\text { How involved should the community } \\
\text { be in food systems initiatives? }\end{array}$ & $\begin{array}{l}\text { Utilize the current structure in which } \\
\text { outreach is the realm of Extension } \\
\text { and Continuing Education. }\end{array}$ & $\begin{array}{l}\text { Incorporate the community into } \\
\text { teaching, research, and outreach. }\end{array}$ \\
\hline
\end{tabular}

was awarded a USDA Challenge Grant to develop an undergraduate, multidisciplinary curriculum for science, economics, and policy in agriculture.

Designed to prepare undergraduate students for employment in the food and agricultural sectors into the twenty-first century, the culminating course engaged 300 students in a cross-disciplinary, project-based experience. While many disciplines related to food systems were represented, the effort was hardly transdisciplinary. Faculty across disciplines participated on a voluntary basis, but each spoke a different research language and used different teaching pedagogies, resulting in tension between natural and social scientists. While faculty members did engage, the project-based experience was seen as an add-on for them and an unrestricted elective for students. No incentives were available. Faculty were not rewarded, students were not required to participate, and no formalized undergraduate curriculum was developed. Despite this, the faculty and students began conversations that helped to build momentum as more food 
systems initiatives evolved, building a base for food systems. The lesson learned: A transdisciplinary approach was "easier said than done."

\section{A food systems minor}

In 2003, several department chairs engaged in discussion about creating an undergraduate food systems minor that would be integrated across departments and not just piece together existing curriculum. Mutual agreement that at least one new course that encompassed the "food system as a system" was needed (e.g., Parr et al., 2007), led to "Farm to Table: Our Contemporary Food System," cross-listed in many departments throughout the university. Within the minor, students choose from courses such that they have an understanding of both the natural and social science aspects of food systems (UVM CALS, 2011).

Unlike the typical one-year approval process for a minor, this initiative took more than three years to move through the governance system because the inclusion of several departments required discussion, revision, and voting at the departmental level before it moved to the college and university level. University governance proved to be cumbersome, but success meant that food systems was officially part of the catalogue. As faculty became interested in cross-unit food systems work, and despite the lack of new resources and coordinated leadership, workloads were juggled and, more importantly, food systems curriculum became available to students university wide.

Since then, food systems has been "seeded" into a variety of coursework. By 2011, 23 new courses with food systems themes built from the bottom up were offered at UVM. Faculty believed that these were strategic and necessary moves toward a transdisciplinary approach and negotiated with chairs so they could deliver these courses while meeting demands of their other workloads. Other student and faculty initiatives were subsequently spawned, but challenges remained.

i. The Honors College picks food systems.

Concurrently with the above initiative, the UVM Honors College hosted a faculty conference with a food systems theme, engaging about 50 faculty from across the university to learn about and discuss food systems. However, without resources, the faculty connections remained informal and fragile. This event might have been more impactful if it had been part of a larger, coordinated effort. ii. A faculty-led, student-run seminar expands food systems thinking and activities. In 2010, four faculty members offered a seminar designed to challenge undergraduate and graduate students to assist university faculty and administrators in developing food systems programming. Experts from across the country were brought together to share their food systems experiences, research, and initiatives. Participating students and faculty mobilized to improve sustainability of food service and beverages on campus, and a weeklong summer intensive food systems course was developed. Several students have continued to mobilize UVM student services toward embracing regional food systems when evaluating choices of contracts. The tenacity and passion of these students and faculty resulted in UVM not renewing its exclusive beverage contract in order allow more options for sourcing locally. The seminar, however, could be characterized in the same way many other initiatives were: one-time events, supported by a single entity (in this case a dean), with no formal linkages to other food systems initiatives. Just as faculty were growing educational opportunities in food systems, students became more educated about food systems issues and felt empowered to use their voices for change.

iii. Student initiatives parallel faculty action: Student voices. Students have been instrumental in the progression of food systems at UVM, demanding real change in the campus wide food system. In 2006 , students demanded more local food on campus and organized a "meet and greet" event for local producers and dining services, which brought local vendors and UVM dining services together to discuss, taste, and debate the triggers and barriers to bringing more local food to our campus. The efforts spawned a master's thesis (Jordan, 2006) and more open communication between vendors and campus buyers. The improved communication, along with student demand, spurred an increase in local purchasing. University Dining Services created a student internship to catalogue local purchases. While these efforts were not yet 
coordinated in any larger university wide effort, the internship continues in its sixth year. The tenacity of students engaged in these grassroots efforts continues to create change in the UVM food system.

$i v$. The Real Food Challenge opportunity. During the 2010 seminar course, undergraduates were introduced to the Real Food Challenge and subsequently worked to persuade the administration to sign the pledge to increase the university's use of local, community-based, fair, ecologically sound, and humane food in campus dining facilities to 20 percent by 2020 (Real Food Challenge, 2011). Providing data and a challenge to the university, the students demonstrated how easily UVM could achieve this goal with UVM's purchase of Real Food, growing from 10 to 12 percent in the last two years (Real Food Challenge, n.d.; Nord, 2011). The Real Food Challenge epitomizes the opportunity to "walk the talk" at a systems level and was signed in March 2012. Faculty helped the students navigate the university landscape, facilitating contact with appropriate administrators. Oversight of the effort was made the responsibility of the university chief of staff, who is charged with moving the initiative forward.

v. Other initiatives provide an opportunity to engage more students. The first national Food Day, held on October 24, 2011 (Food Day, 2011), presented an opportunity for students to become more involved in food systems-related activities. Over 200 students attended two panel discussions and a seminar. However, as with the Honors faculty conference, this was a one-time event accomplished by volunteers with no formal followup. Other ongoing events helpful in engaging students include an on-campus farmer's market, a student-run community supported agriculture operation (CSA), and campus drives to encourage the composting of food waste on campus.

\section{Faculty participate in a national initiative}

Concurrently with developing the food systems minor, UVM cooperatively hosted the Food Systems Leadership Institute (FSLI) with two other universities. It was cosponsored by the W. K. Kellogg Foundation and National Association of State Universities and Land-Grant Colleges
(NASULGC). The FSLI provided "a program dedicated to advancing and strengthening the food system by developing strong and effective leaders prepared to bring cultural change to food system organizations, with a special focus on our nation's land-grant universities" (Food Systems Leadership Institute, n.d., para. 1). Several UVM faculty members were on the planning committee, and others completed the program. While this was an opportunity to network and gain administrative skills, UVM participants felt that UVM was seen as the "rogue" land-grant institution focused more on small to medium-sized diverse and regional food systems. Despite not "finding a place at the table" among the larger universities with a focus on larger monocultural food systems in conventional agricultural models, UVM faculty members were energized and optimistic that there was room "in the market" for the approach UVM planned to take.

\section{Master's level education}

Faculty members saw a need for graduate-level education, not only to train future scientists but also to create a more knowledgeable, systemsthinking workforce that could find employment in the private, not-for-profit, or public sectors. This led to the development of an integrated approach to graduate education in food systems. In 2009, UVM was awarded a second USDA Higher Education Challenge Grant to develop such a graduate program. A broad-based, but voluntary, effort ensued, using direct dollars from the grant to pay for activities aimed at mobilizing and creating synergy among faculty. Faculty participated in informal discussions, and food systems leaders from other universities were invited to visit and share their experiences to strengthen the proposal. While graduate programs at UVM are all housed in the Graduate College, individual departments administer the programs and accept students. The new graduate program will be a test of a "crossuniversity committee approach" to evaluating applicants and determining who will be accepted; it is a major step toward a transdisciplinary effort in food systems.

As with the undergraduate minor, the typically slow university process was challenged by the 
graduate proposal. As it was disseminated across campus, disciplinary silos emerged even though most faculty and administrators were favorably inclined toward the program. Rigor, depth, and breadth were debated. After months of deliberation, discussion, and compromise, the faculty signed on, but questions about resources remain unanswered. The faculty members responsible for shepherding the program through the process volunteered their time, departments put resources on the table in order to gain two graduate assistantships from the administration, and the first year of the program will be funded by the USDA grant.

\section{The Administration Weighs in on Scholarship}

\section{UVM's transdisciplinary research initiative}

In 2009, UVM embarked upon an unprecedented university wide conversation: the Transdisciplinary Research Initiative (TRI). Led by UVM administration, the Faculty Senate, and faculty experts from across campus, the TRI helped map UVM's existing and emerging transdisciplinary strengths in order to further develop areas that can achieve distinctive national and international reputation for research and scholarship. UVM will strategically invest resources to create new knowledge, advance economic development, and engage our communities. The TRI aimed to create foci, or "Spires of Excellence." A proposal to establish a Food Systems Spire of Excellence was competitively reviewed and selected to be one of three Spires of Excellence in 2010, although the idea of food systems being a university wide focus was not readily embraced. The transdisciplinary spire concept had the potential to weave together food systems initiatives that exist across campus.

\section{A committee "steers" the initiative}

In Fall 2010 the provost appointed a steering committee consisting of faculty from across the university to develop metrics and move the Food Systems Spire forward. The committee agreed on a mission statement:

A community of scholars, practitioners, educators, students, and civic partners who actively engage in generating, communicating and applying new knowledge that ensures the present and future viability of smaller-scale food systems, with implications from the local to the global.

The steering committee and UVM community strategically allocated resources from a variety of sources toward promoting collaborations in food systems. Examples of these are shown in table 2.

Table 2. Collaborations Resulting from Strategic Investment of Limited Resources

\begin{tabular}{|c|c|}
\hline $\begin{array}{l}\text { Food Day } \\
\text { Program }\end{array}$ & See Food Day, 2011. \\
\hline $\begin{array}{l}\text { Food Systems } \\
\text { Symposia }\end{array}$ & $\begin{array}{l}\text { An annual event that both brought } \\
\text { faculty together to introduce FS at UVM } \\
\text { (Year 1) and to begin collaborative work } \\
\text { on writing proposals for external } \\
\text { funding and engaged the governing } \\
\text { bodies in the state of Vermont, } \\
\text { including the commissioners from the } \\
\text { agencies of Agriculture, Natural } \\
\text { Resources, Health and Human } \\
\text { Services, and Economic Development } \\
\text { (Year 2). }\end{array}$ \\
\hline $\begin{array}{l}\text { Faculty "Meet } \\
\text { and Greet" }\end{array}$ & $\begin{array}{l}\text { The goal was to start research } \\
\text { conversations between newly hired and } \\
\text { established food systems faculty. }\end{array}$ \\
\hline Planning Grants & $\begin{array}{l}\text { The first round allocated USD } 20,000 \text {. } \\
\text { The second round, as well as a round of } \\
\text { pilot project proposals supported by } \\
\text { UVM deans, awarded almost USD1 } \\
\text { million for use in fiscal year } 2013 \text { to } \\
\text { two relatively large transdisciplinary } \\
\text { pilot projects and one planning grant. }\end{array}$ \\
\hline
\end{tabular}

Structure and process remain barriers to the work of the steering committee, a voluntary work force with no formal authority. While the committee has successfully spearheaded many individual events, the question of what exactly the committee is "steering" and who is at the helm have arisen. Since many units across campus engage in food systems work, a major goal of the committee has been to facilitate communication and collaboration among those interested in food systems. However, free exchange of information and team development are not traditionally fostered in academia. Despite good intentions, when faced with competing demands and interests, individuals and individual units often resort to supporting their "inner circle." Overcoming barriers in communication, leadership styles, and fiscal demands has become a major hurdle. 


\section{Reallocated faculty lines}

In 2010, the university administration re-allocated open faculty positions across the university that would be filled by individuals with disciplinary ties but a "spire focus" in teaching and/or research. Ten new faculty members with food systems expertise were hired in the departments of Animal Science, Anthropology, Geography, the College of Medicine, Community Development and Applied Economics, Extension, and Plant and Soil Science. Nine additional "Spire related" hires have been approved, and searches are underway. The administration effectively moved existing resources into a new strategic direction. However, how new faculty will navigate across the university as well as serve their home departments has not been defined. Current structure remains a barrier. Nevertheless, this innovative approach of reallocating resources led to more cross-university conversations related to transdisciplinary teaching and research.

\section{Bottom-up resource justification}

At the end of 2011, the provost asked the steering committee to provide their concept of the priorities that could help UVM become a "premier small research institution with excellence in food systems," based on the metrics developed by the committee. A substantial budget has been suggested and the administration has a plan to raise those dollars. This is an important and much needed financial commitment that should be forthcoming in fiscal year 2013. In addition, an external advisory board will be appointed. As a land-grant institution, connection with community has been a hallmark since 1862, but this step faces challenges: Who should be on the advisory board? What happens to those who feel excluded? What is its purpose: fund raising, providing advice, strengthening research as well as community ties? To date, some in the outside community already feel excluded despite long-standing outreach and community partnerships that have been central to the development of the transdisciplinary Food Systems Spire of Excellence.

\section{Engaging the Community}

\section{Highlighting community partnerships}

Vermont communities have long been engaged in the arena of smaller, regionally based food systems. To meld the university research mission with community needs, a meeting was held among stakeholders in 2009 to build collaborative relationships, resulting in a food systems research collaborative. A recent census of faculty partnerships at UVM showed that since 2009 more than 100 faculty and 400 community partners have engaged with models and methods that show promise for the realization of the vision. The collaborative invited faculty and community partners to write for a white-paper series, "Opportunities in Agriculture," to incentivize journal publication about food systems. However, just as with several other individual food systems activities, there is no formal support for the collaborative.

Peter Shumlin's election as governor of Vermont in 2010 and his subsequent appointees to the Department of Commerce and Agency of Agriculture brought to the citizens of Vermont a vision of how food systems beyond traditional agriculture can help keep our state economically vibrant through celebration of the Vermont brand and the cachet that our value-added products have in the marketplace. His vision includes implementing a Vermont strategic plan for a vibrant agricultural economy, The Farm to Plate Initiative (Vermont Sustainable Jobs Fund, 2011). This initiative provides UVM with more impetus for a food systems approach, but with it comes the challenge of moving forward while navigating the boundaries between the university's expertise and mission without the community dictating the research and outreach of the university.

Strong outreach and community collaboration presents some unique challenges, as many eyes look in from the outside with their own ideas of what food systems excellence means. With a myriad of partners, not all can have an actual place at the university table. Outreach is only one component of a land-grant university; it must be grounded in evidence-based research and strong academics. The teaching and research missions, 
while informed by the community, are not directed by it.

\section{Continuing education: Educational outreach}

UVM's Division of Continuing Education (CE) has partnered with schools and colleges to extend food systems topics through courses, programs, and lectures to the local, regional, national, and global communities. In 2009, the Department of Nutrition and Food Science and CE launched a food systems-focused semester abroad program in Oaxaca, Mexico, to examine farm-to-plate topics in anthropology, political science, nutrition, botany and plant and soil science. In 2010 CE launched a six-month Farmer Training Program, an entrepreneurial approach to small-scale farming that provides new farmers with the academic and practical knowledge necessary to pursue a career in sustainable agriculture. In June 2012, a Food Systems Leadership Institute was launched with support from the current president. With all this activity, structural issues continue to impede true collaboration and connection of food system education across the university, as individual units have little incentive and many obstacles to working across structural boundaries.

\section{Conclusions}

Transdisciplinary programs that cross traditional university structure lead to uncharted territory. For every successful effort, a barrier appears, but nevertheless there is progress. Sharing UVM's approach and journey toward a holistic, integrated approach to food systems will be helpful to other institutions as they build their food systems programs. We've learned:

- Transdisciplinary approaches have yet to be widely embraced, despite the growing popularity of the buzzword.

- All new initiatives take time, but there are institutional process barriers that lengthen the timeline for establishing food systems programs, which require more than the typical one department or college approval process.

- Momentum is gained as more initiatives and activities occur, but many initiatives are classified as one-time events. There needs to be a dedicated entity to "connect the dots" and communicate success.

- Alignment of the administration, politics, the community, and the faculty is key, but this is not easy to accomplish and is likely a continual work in progress. There needs to be a structure that facilitates communication and coordination.

- A committed core group of faculty, staff, students, and administrators needs to be in place to keep the initiative moving forward, but its work must be communicated widely so as to not perpetuate a perception that people are not included in the efforts.

- University-wide initiatives are difficult to nurture, but the Food Systems Initiative does not, nor should it, sit in a specific department or college. Current university structures (even centers and institutes) do not appear to be as effective as had been hoped to facilitate these endeavors.

- A balance of top down/bottom up approaches is necessary, but tensions between administration and faculty have historically been an issue in institutions of higher education. Transdisciplinary initiatives cause increased tension, and another layer of administration may be needed above the dean's level and below the provost.

- Resources beyond faculty and student interest are necessary. Although many onetime events can be accomplished through volunteer efforts, substantial resources must be found and allocated if food systems is to succeed at an institutional level.

While institutions across the country struggle with transdisciplinary food systems initiatives, the UVM example indicates that regardless of the process, building a base is critical. While different universities may answer the questions highlighted in table 1 in different ways, the UVM experience provides background and context, providing hindsight that can be used as foresight by others in formulating their own food systems approaches. Meanwhile, the UVM initiative continues into fiscal year 2013 . 


\section{References}

Baker, D., Koliba, C., Kolodinsky, J., Liang, K., McMahon, E., Patterson, T., \& Wang, Q. (2009). Moving toward a trans-disciplinary approach in the land grant system: A case study. NACTA Journal, 53(2), 34-42.

Fields, A., Hoiberg, E., \& Othman, M. (2003). Changes in colleges of agriculture at land grant institutions. NACTA Journal, 47(4), 7-15.

Food Day. (2011). About Food Day. Retrieved from http:// foodday.org/about-food-day/

Food Systems Leadership Institute. (n.d.). About The Food Systems Leadership Institute. Retrieved from the Food Systems Leadership Institute website: http://harvest.cals.ncsu.edu/applications/fsli/ index.cfm? showpage $=110$

Galt, R. E., Clark, S. F., \& Parr, D. (2012). Engaging values in sustainable agriculture and food systems education: Toward an explicitly values-based pedagogical approach. Journal of Agriculture, Food Systems, and Community Development. Advance online publication.

http://dx.doi.org/10.5304/jafscd.2012.023.006

Jacobsen, K. L., Niewolny, K. L., Schroeder-Moreno, M. S., Van Horn, M., Harmon, A. H., Chen Fanslow, Y. H.,...Parr, D. (2012). Sustainable agriculture undergraduate degree programs: A land-grant university mission. Journal of Agriculture, Food Systems, and Community Development. Advance online publication. http://dx.doi.org/10.5304/jafscd.2012.023.004

Jordan, H. L. (2006). Marketing local foods in a conventional setting (Unpublished master's thesis). Burlington, Vermont: University of Vermont.

Lieblein, G., Francis, C., Barth-Eide, W., Torjusen, H., Solberg, S., Salomonsson, L., . . . Lund, V. (2000). Future education in ecological agriculture and food systems: A student-faculty evaluation and planning process. Journal of Sustainable Agriculture, 16(4), 4968. http://dx.doi.org/10.1300/J064v16n04 06

Mendes, W., \& Nasr, J. (2011). Preparing future food system planning professionals and scholars: Reflections on teaching experiences. Journal of Agriculture, Food Systems and Community Development, 2(1), 15-52. http://dx.doi.org/10.5304/jafscd.2011.021.022
National Research Council of the National Academies [NRC]; Division on Earth and Life Studies; Board on Agriculture and Natural Resources Board on Life Sciences. (2009). Transforming agricultural education for a changing world. Washington, D.C.: The National Academies Press.

Nord, A. (2011, November). Moving UVM to 20 percent by 2020. Presentation to the UVM Food Systems Steering Committee, Burlington, Vermont.

Parr, D. M., Trexler, C. J., Khanna, N. R., \& Battisti, B. T. (2007). Designing sustainable agriculture education: Academics suggestions for an undergraduate curriculum at a land grant university. Agriculture and Human Values, 24(4), 523-533. http://dx.doi.org/10.1007/s10460-007-9084-y

Pohl, C., von Kerkhoff, L., Hirsch Hadorn, G., \& Bammer, G. (2008). Core terms in transdisciplinary research. In G. Hirsch Hadorn, H. HoffmannRiem, S. Biber-Klemm, W. Grossenbacher-Mansuy, D. Joye, C. Pohl, U. Wiesmann, \& E. Zemp (Eds.), Handbook of Transdisciplinary Research (pp. 427-432). Dordrecht: Springer. http://dx.doi.org/10.1007/978-1-4020-6699-3 28

Real Food Challenge. (n.d.). What we do. Retrieved from http://realfoodchallenge.org/

Real Food Challenge. (n.d.). Real Food Calculator. Retrieved from http://realfoodchallenge.org/ calculator

Strolling of the Heifers. (2012). Vermont tops Strolling of the Heifers Locavore Index; state tops nation in local food availability. Retrieved from http://www.strollingoftheheifers.com/component Lcontent/article/181-locavore-index-2012

U.S. Department of Agriculture, Agricultural Marketing Service. (2011). Number of operating farmers markets [Chart]. Retrieved from http://www.ams.usda.gov/ AMSv1.0/ams.fetchTemplateData.do?template= TemplateS\&navID $=$ WholesaleandFarmersMarket\& leftNav $=$ WholesaleandFarmersMarkets\&page $=$ WFMFarmersMarketGrowth\&description= Farmers \%20Market $\% 20$ Growth\&acct=frmrdirmkt

U.S. Department of Agriculture, Economic Research Service. (2009, September 1). Organic agriculture: Organic market overview. Retrieved from http://www.ers.usda.gov/briefing/organic/ demand.htm 
U.S. Department of Agriculture, National Institute of Food and Agriculture. (2001). NRI annual report:

Fiscal year 2001: National Research Initiative Competitive Grants Program. Retrieved from http://www.nifa.usda.gov/funding/nri/pdfs/ 2001 ann rpt.pdf

U.S. Department of Agriculture, National Institute of Food and Agriculture. (2004). National Research Initiative Competitive Grants Program annual report fiscal year 2004. Retrieved from http://www.csrees.usda. gov/funding/nri/pdfs/ 2004 ann report.pdf

University of Vermont [UVM] College of Agriculture and Life Sciences [CALS]. (2011). Introduction to the newly created Food Systems minor [Brochure]. Retrieved from http://www.uvm.edu/ pss/pssdeptweb/ brochures/Food Systems Brochure.pdf Vermont Sustainable Jobs Fund. (2011). Farm to plate initiative: A snapshot of Vermont's food system. Retrieved from http://www.vsjf.org/project-details/5/farmto-plate-initiative

Wickson, F., Carew, A. L., \& Russell, A. W. (2006). Transdisciplinary research: Characteristics, quandaries and quality. Futures, 38(9), 1046-1059. http://dx.doi.org/10.1016/j.futures.2006.02.011 